\title{
Analysis of Powtoon-Based Learning Media Development in Indonesian Language Subjects
}

\author{
Enny Rahayu ${ }^{1}$, Mutia Febriyana ${ }^{2}$, Halimah Tussadiah ${ }^{3}$ \\ ${ }^{1,2,3}$ Universitas Muhammadiyah Sumatera Utara, Indonesia \\ rahayuenny633@gmail.com,mutiafebriyana@umsu.ac.id, tussadiahhalimah60@gmail.com
}

\begin{abstract}
Student Centered Learning-based learning model which was conducted online in the midst of the Covid 19 pandemic in Indonesian language learning at SMP Muhammdiyah 01 Medan, namely in class VII junior high school students. This study uses a $4 D$ development model (define, design, develop, and disseminate). The subjects of this study were students of SMP Muhammadiyah 01 Medan class VII-A using a small class scale totaling 25 students. Obtaining data through documentation techniques, questionnaires, observation and tests. The data analysis technique used is descriptive quantitative data analysis. The feasibility of learning media refers to the results of media assessments by the developed learning media experts. The results of this study indicate that the powtoon learning media using a student centered learning-based learning model has met the appropriate and valid criteria for use in Indonesian online learning in the midst of the Covid 19 pandemic where in this case learning activities, teacher and student interactions get a percentage of student learning completeness. The test given was $85 \%$. Based on the results of the analysis of student learning outcomes tests, it can be concluded that student learning outcomes tests developed using Powtoon media with a student centered learning based learning model obtained complete criteria.
\end{abstract}

Keywords

organizational culture; transformational leadership; job satisfaction; work motivation; performance

\section{Introduction}

The rapid development and growth in various aspects of life requires the availability of human resources who have knowledge and skills so that they can support the development and growth itself. Superior human resources will lead a nation to be the spearhead for the birth of superior and quality human resources. Humans can increase their basic potential, both physical, intellectual, social and spiritual potential through education. The statement is in accordance with the objectives of national education in(Republic of Indonesia, 2003)that "National education functions to develop and shape the character and civilization of a nation with dignity in the framework of educating the nation's life, aiming at developing the potential of students to become human beings who believe and fear God Almighty, have noble character, are healthy, knowledgeable, capable, creative, be independent, and become democratic and responsible citizens".

Education is a conscious and planned effort to create an atmosphere of learning and the learning process so that students actively develop their potential to have religious spiritual strength, self-control, personality, intelligence, noble character, and skills needed by themselves, society (National, 1982). Sitorus (2019) states that Education is one way to produce quality Human Resources (HR) with experience changes in knowledge, skills and 
attitudes. These changes can be a capital to improve selfcompetence in facing the era of globalization that always undergo the change (Gaol et al, 2020).

Educational goals can be achieved if the educational process has been well structured and directed. One important part of the educational process that can support the achievement of educational goals is the learning process. Factors that influence the learning process include educators and students. In this case, the teacher and students carry out a reciprocal relationship that is educational in order to achieve learning objectives. This reciprocal relationship demands the readiness of students to be more active, the teacher acts as a guide, manager and facilitator of the learning process. Therefore, teachers are always required to be able to create a learning atmosphere that is interesting, fun and motivates student learning.

Indonesian language has been communication tool among countries around ASEAN (Association of Southeast Asian Nations) regional. The number of foreign students increased significantly in Indonesia. They studied through three ways; Indonesian as communicative tool, art and culture to know habit, social life and sociocultural to understand Indonesian community. These can be learnt by studying Indonesian language integrated with culture. The development of Indonesian teaching in Indonesia required good learning materials and based on the students' need. Teachers must be more creative in developing learning materials to be more interesting and favoured by students (Darmuki, et.al, 2018). People studied culture using some processes, for example seeing, predicting, feeling, staying and connecting with others (Stuart et.al., 1996). In the learning of Indonesian language, they also studied habit, attitude, ethics, and environment (Nurlina et al, 2020).

Indonesian language subject is one of the core subjects in school. There are interconnected subject matter in Indonesian subjects which include aspects of language learning and literature learning. Related to this, students are required to understand in advance how to master the two core areas of the Indonesian language subject. Based on the results of the researchers' observations, students have difficulty understanding the teaching material delivered by the teacher. In addition, students have not been maximal in carrying out the assignment given so that it affects learning outcomes. Students have not fully received the value according to the minimum completeness criteria. Another cause is that the learning carried out is still limited to using the recitation method and without using effective learning media. This has an impact on an unpleasant learning atmosphere for students so that students are not motivated to be actively involved in the implementation of learning in class. In this case, the teacher still uses the power point media presentation in carrying out teaching and learning activities in the classroom. The opposite condition is currently, teachers and students are carrying out online learning in the midst of the Covid 19 pandemic.

Learning is essentially a cognitive process that has the support of psychomotor functions. The psychomotor function in the learning manifestations carried out by students, almost certainly always involves a function of the realm of reason whose intensity of use is certainly different from other learning events. (Arsani et al, 2020)

In order to make learning fun and successful for students, it takes the skills of teachers to choose learning media according to the character of students and student needs. The selection of learning media cannot be done arbitrarily. From the observations made by the researchers, it was easier for students to absorb learning material using media in the form of using pictures or short videos. The use of these short pictures or videos definitely requires an application. Therefore, the research used powtoon learning media. Powtoon is a web application used to create attractive presentations that can help students better understand the subject matter. This learning media will make it easier for students to understand and solve various obstacles to learning Indonesian at school, because in addition to being interesting, this media can be created and developed by both teachers and students themselves in the future. Based on the 
description above, researchers are interested in conducting research by looking for the development of learning media using the powtoon in Indonesian subjects for students of SMP Muhammadiyah 01 Medan.

This research is a follow-up study from existing research. Previous studies have become an impetus for researchers to carry out further research. The first relevant research was conducted by Fajar et al., 2017 entitled "The Influence of Using Powtoon Media on Student Learning Outcomes in Integrated Social Sciences Subjects". The research conducted by Fajar et al is an experimental study, namely conducting a cona test of using powtoon media in Integrated Social Sciences learning. Research result (Fajar et al., 2017)In general, it can be concluded that there are significant differences in learning outcomes in the coognitive domain between students learning using Powtoon media and students learning using Microsoft PowerPoint 2016 media in Integrated Social Sciences subjects in Junior High Schools. In addition, there is a second relevant research conducted by(Puspitarini et al., 2018)entitled "Developing Powtoon-Based Video Learning Media for Five Grade Students of Elementary School" it can be concluded that the media developed in the form of powtoon-based video learning tools is in a good category and is suitable for use as learning media. Furthermore, the third relevant research by(Juliana, 2018) explain that differences and similarities, the difference between the results of the above research and this research lies in the feasibility test of the powtoon learning media which is aligned with the student centered learning-based learning model in its online implementation in Indonesian language learning for grade VII SMP level. The similarities are both researching the powtoon learning media. The findings analyzed from various previous studies have become one of the bases for conducting research with a focus on developing powtoon learning media in Indonesian online learning at SMP Muhammadiyah 01 Medan. The formulation of the problem in this study is described as follows (1) How is the validity of the development of learning media using the powtoon in Indonesian subjects for students of SMP Muhammadiyah 01 Medan?

\section{Research Methods}

This study uses the Research and Development (R\&D) method in the form of field research, namely the application of the development of Powtoon-based learning media. This research was conducted at SMP Muhammadiyah 01 Medan. The population of this study were two classes of class VII junior high school students. Meanwhile, the sample in this study was one class, namely class VII-A which was randomly selected.

This research is an applied research that develops powtoon application-based learning media in Indonesian subjects. This study uses a 4D development model (define, design, develop, and disseminate). At the define stage, researchers understand the problems that occur in students and in the learning media. The problems are collected and then searched for solutions. It turns out that in the Indonesian language subject, students find it difficult to understand the material presented because the use of learning media is not effective for students. Students need guidance in completing Indonesian subjects. Thus, in this study, researchers developed powtoon-based learning media. At the design stage, researchers designed the powtoon learning media. In the learning media, it is explained in detail how the Indonesian learning material is described in an animated display as attractive as possible for students so that it raises students' enthusiasm for learning. At the develope stage, the researcher validates the initial draft / draft 1 by the validator in the material and development field. After being validated, the researcher revised the things that became the validator's notes so that the teaching materials became better into draft 2 . Then the researcher tested the 2 nd 
draft on students of SMP Muhammadiyah 01 Medan in the 2019/2020 Academic Year, class VII. After being revised, the researcher obtained the final draft. At the disseminate stage, researchers distributed valid teaching materials (final draft) in a small area, namely to class VII-A students by teachers teaching Indonesian subjects.

\section{Result and Discussion}

This study uses a 4D development model (define, design, development and disseminate). At the define stage, researchers understand the problems that occur in students and in the learning media. The results of observations through direct interviews with class VII-A Indonesian teachers showed that the needs of class VII-A students of SMP Muhammadiyah 01 Medan were as follows. (1) Analysis of Student Needs, the use of Indonesian learning media used in class is still limited to the use of Power Points. Likewise with the form of online learning which is still limited to presenting power points. The conditions for online learning were enforced during the Covid 19 pandemic, where teachers

Students conducted online learning through google classrooms, which contained power point content. The presentation of the material on the power point slides made students feel bored because the visuals were monotonous. In addition, teachers are still limited to conventional learning models. Has not involved the active role of students in learning activities. (2) Analysis of Student Characteristics, analysis of characteristics in students that do not fully understand the concept of teaching material provided by the teacher. Considering the implementation of learning in compulsory schools based on student centered learning. So in this case, students are required to be independent in understanding the material presented. Characteristic analysis of students that not all of them understand the concept of teaching material provided by the teacher. Considering the implementation of learning in compulsory schools based on student centered learning. So in this case, students are required to be independent in understanding the material presented. Characteristic analysis of students that not all of them understand the concept of teaching material provided by the teacher. Considering the implementation of learning in compulsory schools based on student centered learning. So in this case, students are required to be independent in understanding the material presented.

Based on the results of the interview, grade VII students at SMP Muhammadiyah 01 Medan often use laptops as a means of learning online from home and in class. So in this case, it can be concluded that students are already proficient in using laptops as a medium of information as well as a means of independent learning. (3) Curriculum analysis, the curriculum used at SMP Muhammadiyah 01 Medan is the 2013 curriculum. Thus, the implementation of learning is always in line with the achievements in the 2013 curriculum, which is based on sanitive learning where the active role of students also supports learning success and learning outcomes. (4) Technology analysis, Powtoon is an animation medium in the form of online software which is used as a superior media because it consists of multimedia displays in the form of motion animation, sound effects, Interesting 2D and 3D screen backgrounds that use easily adjustable time durations. Based on the results of observations, each learning classroom has been provided with a protective screen for use by teachers and students in material presentation activities. The use of protective screens is often used. Therefore, learning activities in class can be said to be based on active learning media. The opposite condition is in online learning, the presentation of material by the teacher is carried out in the google classroom which consists of material content and assignments that must be independently mastered and understood by students. The use of protective screens is often used. Therefore, learning activities in class can be said to be based on active learning media. The opposite condition is in online learning, the presentation of material by the teacher is carried 
out in the google classroom which consists of material content and assignments that must be independently mastered and understood by students. The use of protective screens is often used. Therefore, learning activities in class can be said to be based on active learning media. The opposite condition is in online learning, the presentation of material by the teacher is carried out in the google classroom which consists of material content and assignments that must be independently mastered and understood by students.

Furthermore, at the design stage, the researcher designed the powtoon learning media. In the learning media, it is explained in detail how the Indonesian learning material is described in an animated display as attractive as possible for students so as to generate enthusiasm for student learning. At the develope stage, the researcher validates the initial draft / draft 1 by the validator in the material and development field. The results of the assessment by the validator are useful for knowing whether the learning media is feasible to be developed. The media developed is based on learning scenarios prepared by the teacher. Then the media that has been developed is assessed by experts. The following are the results of the assessment of the powtoon learning media by media experts.

Table 1. Media Assessment Results

\begin{tabular}{|c|c|c|c|c|}
\hline \multirow[t]{2}{*}{ Rated aspect } & \multicolumn{3}{|c|}{ Validator } & \multirow[t]{2}{*}{ Average } \\
\hline & 1 & 2 & 3 & \\
\hline $\begin{array}{l}\text { Learning media is useful for making } \\
\text { information clearer and easier for } \\
\text { students to understand }\end{array}$ & 4 & 5 & 4 & 4 \\
\hline $\begin{array}{l}\text { The learning media used are able to } \\
\text { focus students' thoughts and } \\
\text { attention on the information / } \\
\text { concepts / principles being taught }\end{array}$ & 5 & 5 & 4 & 4 \\
\hline $\begin{array}{l}\text { The learning media used are adaptive } \\
\text { or can change flexibly and } \\
\text { spontaneously to provide feedback } \\
\text { on responses / reactions, or student } \\
\text { answers during the online learning } \\
\text { process }\end{array}$ & 4 & 4 & 4 & 5 \\
\hline $\begin{array}{l}\text { The learning media used help } \\
\text { students be more active and } \\
\text { physically / psychomotor involved }\end{array}$ & 4 & 4 & 4 & 4 \\
\hline $\begin{array}{l}\text { The learning media used helps } \\
\text { students be more active and } \\
\text { emotionally involved (involving the } \\
\text { heart and feelings) }\end{array}$ & 4 & 4 & 4 & 4 \\
\hline $\begin{array}{l}\text { The learning media used involves the } \\
\text { use of various senses as channels of } \\
\text { information }\end{array}$ & 4 & 4 & 4 & 4 \\
\hline
\end{tabular}




\begin{tabular}{|c|c|c|c|c|}
\hline $\begin{array}{l}\text { The media used is able to encourage } \\
\text { students to be more involved in high- } \\
\text { level cognitive activities (problem } \\
\text { solving, creative thinking, creativity } \\
\text { in creating, innovating, etc.) in } \\
\text { accordance with the stages of } \\
\text { children's } \\
\text { development. }\end{array}$ & 4 & 4 & 4 & 4 \\
\hline Average total score & 4,1 & 4,2 & 4,1 & 4,1 \\
\hline
\end{tabular}

After being validated, the researcher revised the things that became the validator's notes so that the teaching materials became better into draft 2 . Then the researchers tested the 2 nd draft on students of SMP Muhammadiyah 01 Medan in the 2019/2020 Academic Year, class VII-A. The results of product trials using a small scale with a sample of 25 people in class VIIA SMP Muhammadiyah 01 Medan. The results of these trials show student learning outcomes tests through the use of the powtoon learning media.

Table 2. Learning Test Results on Product Test Powtoon Learning Media

\begin{tabular}{c|c|c|c}
\hline No. Sort Students & Test Value & Mastery learning & Criteria \\
\hline 1 & 85 & 85 & $\mathrm{~T}$ \\
\hline 2 & 75 & 75 & $\mathrm{~T}$ \\
\hline 3 & 60 & 60 & $\mathrm{TT}$ \\
\hline 4 & 75 & 75 & $\mathrm{~T}$ \\
\hline 5 & 85 & 85 & $\mathrm{~T}$ \\
\hline 6 & 90 & 90 & $\mathrm{~T}$ \\
\hline 7 & 100 & 100 & $\mathrm{~T}$ \\
\hline 8 & 80 & 80 & $\mathrm{~T}$ \\
\hline 9 & 85 & 85 & $\mathrm{~T}$ \\
\hline 10 & 85 & 85 & $\mathrm{~T}$ \\
\hline 11 & 90 & 90 & $\mathrm{~T}$ \\
\hline 12 & 100 & 100 & $\mathrm{~T}$ \\
\hline 13 & 100 & 100 & $\mathrm{TT}$ \\
\hline 14 & 60 & 60 & $\mathrm{~T}$ \\
\hline 15 & 75 & 75 & $\mathrm{~T}$ \\
\hline 16 & 85 & 85 & $\mathrm{~T}$ \\
\hline 17 & 90 & 90 & $\mathrm{~T}$ \\
\hline 18 & 80 & 80 & $\mathrm{~T}$ \\
\hline 19 & 75 & 75 & 85 \\
\hline 20 & 85 & & \\
\hline
\end{tabular}

T= Completed $; T=$ Incomplete

Based on the data in the table above, it can be concluded that the individual learning completeness criteria of students who get a completeness score are 18 students with a percentage of $80 \%$ and students who do not get a completeness score are 2 students with a percentage of $20 \%$. In other words, the classical product trials have achieved mastery learning. At the disseminate stage (disseminate), Powtoon learning media are not only presented in online classrooms but also packaged in DVD products for later use by teachers in presenting teaching materials in class. 


\section{Conclusion}

Based on the above discussion, it can be concluded that the Indonesian language learning media using the powtoon and the student centered learning based learning model developed have met the feasibility test and are valid for use for SMP Muhammadiyah 01 Medan. This feasibility can be seen from the acquisition of an average value assessed by the validator with a score of 4.1 in the good category. Likewise, the percentage of student learning completeness that is $80 \%$ reaches a complete score of 75 and even exceeds the standard value of learning completeness.

\section{Suggestion}

The use of powtoon learning media is proven to be able to make it easier for students to understand the material presented by the teacher and to make students more active in online learning activities.

\section{References}

Arsani, et al. (2020). Differences in Motivational Orientation in Physical Education in terms of Gender Differences. Budapest International Research and Critics in Linguistics and Education (BirLE) Journal. P. 1428-1434.

Arsyad, A. (2015). Media Pembelajaran, Jakarta: PT. Raja Grafindo Persada.

Fajar, S., Riyana, C., \& Hanoum, N. (2017). Pengaruh Penggunaan Media Powtoon Terhadap Hasil Belajar Siswa Pada Mata Pelajaran Ilmu Pengetahuan Sosial Terpadu. Jurnal Pengajaran MIPA.

Gaol, R. et al. (2020). The Influence of Used Good-Based Learning Media on the Value of Chracter Education and Student's Motivation to Study. Budapest International Research and Critics in Linguistics and Education (BirLE) Journal. P. 1696-1703.

Juliana, P. I. (2018). Pengembangan Media Pembelajaran Berbantu Powtoon Dengan Model Pembelajaran Creative Problem Solving ( Cps ) Untuk Meningkatkan Kemampuuan Pemecahan Masalah Siswa. 190-201.

Nurlina, L. et al. (2020). The Ways to Develop Indonesian Learning Material Enriched by Local Culture for Foreign Students. Budapest International Research and Critics in Linguistics and Education (BirLE) Journal. P. 1045-1055.

Puspitarini, Y. D., Akhyar, M., \& Djono, D. (2018). Developing Powtoon-Based Video Learning Media for Five Grade Students of Elementary School. https://doi.org/10.2991/iccsr-18.2018.37

Republik Indonesia. (2003). Undang-Undang Sistem Pendidikan Nasional No. 20 Tahun 2003. Sekretariat Negara. https://doi.org/10.16309/j.cnki.issn.1007-1776.2003.03.004

Sukiman. (2012). Pengembangan Media Pembelajaran. Yogyakarta: Pedagogia.

Villar, Mayra Aixa. (2013). Developing A Mobile Learning Strategi. Amerika: ASTD. 